\title{
POTENCY OF PAPER MILL WASTE AS RECYCLABLE POL YPROPYLENE FILLED WITH COCONUT FIBER COMPOSITE FOR MITIGATIONAL MATERIAL
}

\author{
Elda Pelita*, Tengku Rachmi Hidayani and Dedy Rahmad \\ Politeknik ATI Padang, Jalan Bungo Pasang Tabing Padang 25171, Indonesia \\ *E-mail: elda726@gmail.com
}

\begin{abstract}
Regarding its geographical location, West Sumatra is an area prone to earthquakes. The solution to this condition is by mitigating the effects through the construction of earthquake-resistant buildings. Earthquake-resistant buildings may be constructed by replacing polymeric materials with characteristics of light, durable and good flexibilities. One of which by replacing stone as common building structure with composite material. Composite wall panels that are expected to be utilized to construct a resistant building, are made by mixing polypropylene plastic waste with coconut fiber and primary sludge from paper mill waste. The mixing method was performed using an extruder (dry mixing with heat). Composition of coconut fiber, primary sludge, and paper mill waste were 20:20:60, respectively based on the previous study. Method for casting composite wall panels was performed using hot-press. The composite wall panels showed a flexural properties of $9.6 \mathrm{~N} / \mathrm{mm}^{2}$, modulus of elasticity of $2,640 \mathrm{~N} / \mathrm{mm}^{2}$, melt temperature at $161.21^{\circ} \mathrm{C}$, combustion point at $463.55^{\circ} \mathrm{C}$, decomposition point at $476.99^{\circ} \mathrm{C}$, carbon residue of $15.1 \%$, density of $1.093 \mathrm{~g} / \mathrm{cm}^{3}$, thickness swelling of $0.104 \%$, internal bond strength of $0.61 \mathrm{~N} / \mathrm{mm}^{2}$, a good morphochemical interaction and following EN 634-2-2007 standard.
\end{abstract}

Keywords: Coconut Fiber, Composite, Earthquake-resistant Building, Plastic Waste, Sludge, Wall Panels.

(C) RASĀYAN. All rights reserved

\section{INTRODUCTION}

West Sumatra is a province prone to earthquake due to its geographical location on the west coast of Sumatra, which is tectonically adjacent to the subduction zone. The subduction zone is a meeting zone between two tectonic plates in the form of subduction of Indo-Australia plate to underneath of Eurasia plate. Movement of these plates will cause a considerable strong earthquake. In addition, an active Great Sumatran fault is a major threat to that area if movement occurred in the fault zone. Moreover, active volcanoes, e.g. Marapi, Tandikat, and Talang may also cause a quite strong vibration. The subduction zone, Great Sumatran fault, and active volcanoes, are contributing each other to cause an earthquake ${ }^{1-3}$.

Earthquake is an unpredictable natural event with tremendous impacts of destruction that needed to be mitigated. The common development of technology by various parties is by constructing an earthquakeresistant building made of simple construction using a type of lightweight construction and structural materials as well as lightweight roofs and wall coverings ${ }^{4-11}$. The wall panels are the main elements that suffered the most damages from earthquakes. A simple, fast-build house supporting structure can be made from polymer composite frames. In principle, the design can maintain structural rigidity and possess the flexibility to flow with the earthquake, and maintain the roof and wall cover tightly with minor damage. ${ }^{7,12-14}$ Numerous studies have reported the production of wall panels made from composites for construction of earthquake-resistant building. ${ }^{15-18}$ Wall panels impregnated with sludge from paper mill waste is one example. Sludge contains a similar chemical composition to cement, supporting their use as a replacement of cement in manufacturing of composite wall panels. The results of composite wall panels obtained showed variations in composite load while the composition of coconut fibers also contributed to its mechanical characteristics, with optimum flexural stress of $8 \mathrm{MPa}{ }^{19}$

Rasayan J. Chem., 12(3), 1144-1150(2019)

http://dx.doi.org/10.31788/RJC.2019.1235345

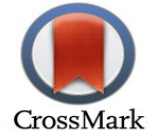


Nowadays, wood plastic composites (WPC) are one of the most dynamic sectors of the plastic industry. The material consists of a mixture of wood fiber or similar structure with thermoplastic polymers such as polyethylene (PE), polypropylene (PP), etc. Thermoplastic polymers are soft in certain elevated temperature and rigid under low temperature. These properties allow other materials to be mixed such as wood or similar particles to form a composite material ${ }^{20-22}$. Sludge (paper mill waste) was considered a major problem in the paper industry although it is commonly utilized as plant fertilizer. The sludge contains mainly (95\%) organic fiber in the form of cellulose mimicking the properties of cement, which can be a promising additive in the production of wall panel composites with good physical properties. Sludge is categorized into 2 types, namely primary sludge which still contains cellulose and hemicellulose and secondary sludge which has been separated from the solids ${ }^{23-28}$. Integration of sludge to the composite material may increase the mechanical strength of the composite.

Fabrication of composite wall panels using a combination of plastic waste, primary sludge, and coconut fibers, is expected to produce an earthquake-resistant material with the support to environmental recycling. The advantages of this product include low production costs, availability of raw materials, flexibility in the manufacturing process, low density, environmentally friendly, and better properties than the original raw material. The manufacture of composite boards has been achieved through mixing of coconut fiber with polypropylene waste by reflux method ${ }^{29}$. The obtained results are considered good in terms of physical and chemical properties, with several drawbacks in appearance and expensive manufacturing costs. But to obtain a promising result in terms of homogeneity, low-cost production and environmentally friendly, the technique to produce the composite wall panels should be changed and followed the advancement of technology, using an extruder machine to achieve well-blended material. Integration of sludge as composite materials is expected to enhance the physicochemical characteristics of wall panels resembling the cement panels. A dry mixing method using an extruder is then applied to produce a homogeneous mixture with a small production cost. To determine the characteristics of composite wall panels, several parameters are evaluated including: Mechanical impact strength, Modulus of elasticity, Density, Physical image under Scanning Electron Microscope (SEM), Thickness swelling, Internal bond strength, differential thermal analysis (DTA), thermogravimetry analysis (TGA), and chemical group characteristics using Fourier Transform-Infra Red (FT-IR) images.

\section{Materials}

\section{EXPERIMENTAL}

Materials used in this study were: polypropylene plastic waste, coconut fiber, aquadest, primary sludge (paper mill waste).

\section{General Procedure \\ Preparation of Coconut Fiber}

Coconut fiber was removed from its shell, cut into homogenous sizes forming a tiny fiber. Coconut fiber was then dried in an oven at $50^{\circ} \mathrm{C}$ until constant weight prior to laboratory experimentation.

\section{Preparation of Polypropylene Plastic Waste (PPW)}

Polypropylene plastic waste was washed by water and dried under sunlight. Then, PPW was cut into a smaller segment of $0.25 \mathrm{~cm}^{2}$.

\section{Preparation of Primary Sludge}

The primary sludge was obtained from several paper industries in Riau. The sludge was dried under sunlight for 7 days, followed with oven-drying at $110^{\circ} \mathrm{C}$ for $6 \mathrm{hr}$. The dried sludge was blended and sieved using a 200-mesh sieve.

\section{Fabrication of Composite Wall Panels}

The extruder instrument was set prior to experimentation to achieve a temperature of $160^{\circ} \mathrm{C}$. The coconut fiber, PPW and primary sludge were mixed in the ratio of 60:20:20, respectively and homogenized. The mixture was inserted into extruder gradually through a plastic funnel until the blending out through the tip 
of the extruder barrel. The polyblend was pooled and cooled in ambient temperature. Polyblend was then placed into a steel template with a dimension of $20 \times 15 \times 1 \mathrm{~cm}$ that has been priorly coated with aluminum foil. The sample was placed between two heaters $\left(160^{\circ} \mathrm{C}\right)$ for $\pm 10 \mathrm{~min}$ without pressure. The pressure was then given gradually for $\pm 20 \mathrm{~min}$. The instrument was turned off and allowed to cool to $90^{\circ} \mathrm{C}$. The sample was removed and left in the water to reach ambient temperature.

\section{Mechanical Properties of Composite Panels}

\section{RESULTS AND DISCUSSION}

The analysis result of mechanical properties from composite wall panels with the addition of sludge are listed in Table-1.

Table-1: Physical Characteristics Result

\begin{tabular}{c|c|c|c|c|c}
\hline & Composition & $\begin{array}{c}\text { Modulus of } \\
\text { Elasticity } \\
\left(\mathrm{kgf} / \mathrm{cm}^{2}\right)\end{array}$ & $\begin{array}{c}\text { Flexural Strength } \\
\left(\mathrm{N} / \mathrm{mm}^{2}\right)\end{array}$ & $\begin{array}{c}\text { Modulus of } \\
\text { Elasticity } \\
\left(\mathrm{kgf} / \mathrm{cm}^{2}\right)\left(10^{4}\right)\end{array}$ & $\begin{array}{c}\text { Modulus of } \\
\text { Elasticity } \\
\left(\mathrm{N} / \mathrm{mm}^{2}\right)\end{array}$ \\
\hline 1 & $\begin{array}{c}\text { Composite 1 } \\
\text { (PPW:Coconut fiber, 60:40) }\end{array}$ & 90.509 & 8.8 & 3.672 & 3601 \\
\hline 2 & $\begin{array}{c}\text { Composite 2 } \\
\text { (PPW: Coconut fiber: sludge, } \\
\text { 60:20:20) }\end{array}$ & 98.266 & 9.6 & 2.693 & 2640 \\
\hline
\end{tabular}

Flexural tests measure the ability of materials to resist deformation under load. ${ }^{30}$ The composites 2 presented a higher flexural strength value than the composites 1 . The mechanical characteristics of composite 2 are different in terms of better resistance than composite 1 . The impregnation of sludge into the mixture of composite 2 strengthen the wall panels due to its similar properties with cement. The modulus of elasticity (MOE) from composite 2 is quite low since the sole properties of PPW is now reacted physically with fiber and sludge reducing its elasticity. Klyosov ${ }^{31}$ has stated that the improvement of flexural strength rarely agrees with the improvement of elasticity modulus, which is congruent with the comparison of the flexural properties of the sludge-treated and composites 1 . The flexural strength obtained from this composite is known to achieve the European Standard EN 634-2 in the standardization of the cement-particle board with a minimum flexural strength of $9 \mathrm{~N} / \mathrm{mm}^{2}$ and maximum MOE of 4500 $\mathrm{N} / \mathrm{mm}^{2}$.

\section{Thermal Properties of Composite Panels}

The analysis of thermal resistance can be seen from DTA and TGA tests in Table-2. The DTA test showed the melting and combustion point of composite panels while the TGA test showed the decomposition point of which carbon residue is yielded.

Table-2: Results of DTA and TGA Tests

\begin{tabular}{c|c|c|c|c|c}
\hline & Composition & $\begin{array}{c}\text { Melting point } \\
\left({ }^{\circ} \mathrm{C}\right)\end{array}$ & $\begin{array}{c}\text { Combustion } \\
\text { point }\left({ }^{\circ} \mathrm{C}\right)\end{array}$ & $\begin{array}{c}\text { Decomposition } \\
\text { point }\left({ }^{\circ} \mathrm{C}\right)\end{array}$ & $\begin{array}{c}\text { Residue } \\
(\%)\end{array}$ \\
\hline 1 & $\begin{array}{c}\text { Composite 1 (PPW:Coconut fiber. } \\
\text { 60:40) }\end{array}$ & 161.62 & 462.03 & 470.89 & 13.2 \\
\hline 2 & $\begin{array}{c}\text { Composite 2 } \\
\text { (PPW: Coconut fiber: sludge, } \\
\text { 60:20:20) }\end{array}$ & 161.21 & 463.55 & 476.99 & 15.1 \\
\hline
\end{tabular}

From thermal properties analysis, we can obtain information on physical changes in composite panels, for example melting points and occurrence of chemical processes that include polymerization, degradation, and decomposition. From the results, it can be seen that the addition of sludge increases the combustion point of composite 2, as reported earlier. ${ }^{32}$ A slight decrease in melting point is observed from composite 2 as well. Alteration in melting and combustion point of composite 2 indicated that interaction between materials occurred which affect the thermal properties. ${ }^{33}$ However, the expected result from this experimentation is that the addition of sludge will not significantly alter the properties of polypropylene, but increase the combustion point. In addition, composite 2 tend to decompose at higher temperature as 
showed from its decomposition point and produce residues in a greater percentage. The condition is known to occur due to the high organic content of sludge in composite 2.

\section{Morphology of Composite Panels}

Analysis of the surface condition of morphological characteristics of composite panels using SEM under $1000 \times$ magnification at fractured wall panels. The morphological images are presented in Fig.-1 and Fig2.

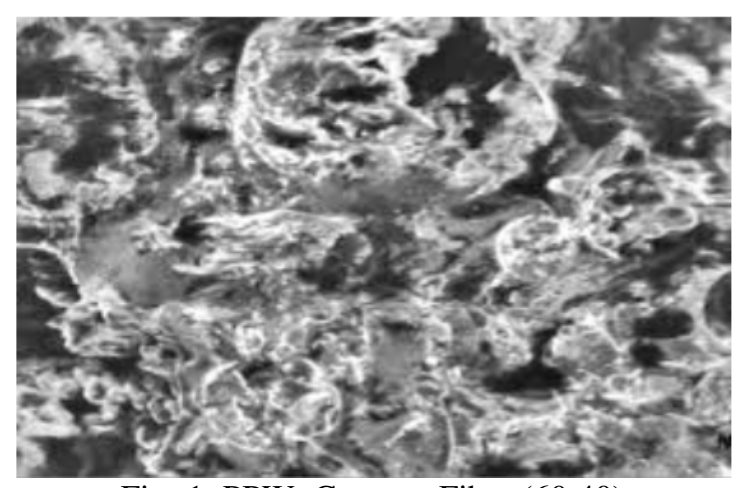

Fig.-1: PPW: Coconut Fiber (60:40)

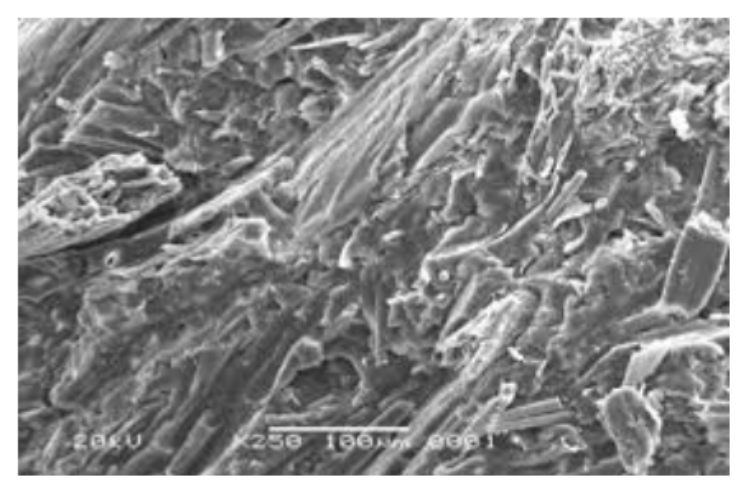

Fig.-2. PPW: Coconut Fiber : Sludge (60:20:20)

The samples used in microscopy investigation were cross-section fracture of composite wall panels. Figure-1 showed the fracture within composite 1 that appears to be in a homogenous phase although obvious differences can be seen in the color of materials showing the different mixture of each component. Figure-2 showed indistinguishable color which indicates a good interaction among filler components. However, on a microscopic level, both panels did not show any distinctive features which are homogenous.

\section{Density Test}

The density of composite panels is defined as the ratio of the weight of the composite material to its volume. The density value from each composite is presented in Table-3.

Table-3: Density Test Result

\begin{tabular}{c|l|l}
\hline & Composition & Density $\left(\mathrm{g} / \mathrm{cm}^{3}\right)$ \\
\hline 1 & $\begin{array}{l}\text { Composite 1 } \\
\text { (PPW:Coconut fiber. 60:40) }\end{array}$ & 0.9713 \\
\hline 2 & $\begin{array}{l}\text { Composite 2 } \\
\text { (PPW: Coconut fiber: sludge, 60:20:20) }\end{array}$ & 1.093 \\
\hline
\end{tabular}

The impregnation of sludge into composite 2 mixture increased the density of wall panels due to the fine structure with a size of 200 mesh. The density of wall panels has met the requirement by EN 634-2 regarding cement-bonded particle board with a minimum density of $1 \mathrm{~g} / \mathrm{cm}^{3}$. 
RASĀYAN J. Chem.

Vol. 12 | No. 3 |1144 - 1150| July - September | 2019

\section{Thickness Swelling Test}

The thickness swelling after soaking in water is one of the physical properties which determines the application of wall panels for interior and exterior purposes. The analytical method is by measuring the thickness of the wall at the center with an accuracy of $0.05 \mathrm{~mm}$. The panels are then immersed in water at $25^{\circ} \mathrm{C}$ horizontally, at a distance of $3 \mathrm{~cm}$ from water surface \pm 24 hours. The panels are then removed, wiped and measured for its thickness.

Table-4: Thickness Swelling Test Result

\begin{tabular}{l|c|c|c|c}
\hline & Composition & Initial Thickness (mm) & Final Thickness (mm) & $\begin{array}{c}\text { Thickness } \\
\text { Swelling (\%) }\end{array}$ \\
\hline 1 & $\begin{array}{c}\text { Composite 1 } \\
\text { (PPW:Coconut fiber. 60:40) }\end{array}$ & 9.83 & 9.88 & 0.508 \\
\hline 2 & $\begin{array}{c}\text { Composite 2 } \\
\text { (PPW: Coconut fiber: } \\
\text { sludge, 60:20:20) }\end{array}$ & 9.58 & 9.59 & 0.104 \\
\hline
\end{tabular}

Based on Table-4, it can be seen that composite 2 produced a lower percentage of thickness swelling than composite 1. This is due to its greater density caused by sludge insertion into panels which hinder the panels ability to absorb water more readily. The percentage of thickness swelling is insignificant because the matrix used is a type of hydrophobic polypropylene. The percentage of $0.104 \%$ has also met EN 6342 with maximum thickness swelling of $1.5 \%$ after 24 hours of immersion in water.

\section{Internal Bond Strength Test}

Internal bond strength value is obtained to determine the hardness of composite panels interacting with other objects.

Table-5: Internal Bond Strength Test Result

\begin{tabular}{c|l|c}
\hline \multicolumn{1}{|c|}{ Composition } & $\begin{array}{c}\text { Internal Bond Strength } \\
\left(\mathrm{N} / \mathrm{mm}^{2}\right)\end{array}$ \\
\hline 1 & $\begin{array}{l}\text { Composite 1 } \\
\text { (PPW:Coconut fiber. 60:40) }\end{array}$ & 0.59 \\
\hline 2 & $\begin{array}{l}\text { Composite 2 } \\
\text { (PPW: Coconut fiber: sludge, 60:20:20) }\end{array}$ & 0.61 \\
\hline
\end{tabular}

Based on Table-5, it can be seen that composite 2 showed a slightly better internal bond strength because the structure is more robust. The internal bond strength of $0.61 \mathrm{~N} / \mathrm{mm}^{2}$ also meets the standard of EN 6342 with the minimum internal bond strength value of $0.5 \mathrm{~N} / \mathrm{mm}^{2}$.

\section{Fourier Transform-Infra Red (FT-IR)}

The FT-IR test was performed to identify the functional groups residing within composite panels. Through the functional groups, we may conclude whether the interaction between PPW, coconut fiber and sludge reacts in terms of chemical or physical bonds (hydrogen bonds). Chemical bonds have better strength than hydrogen bonds so that the presence of chemical bonds in the resulting composite wall panels is expected to increase the resistance of the resulting composites. The wavenumber of composite 2 can be seen in Table-6.

From the results, it can be seen that the wavenumber of composite wall panels showing interactions between elements in the mixture of composite 2. A typical functional group in composite 2, namely $3193.41 \mathrm{~cm}^{-1}$ indicated the sludge element which is supported by wave number $1645.40 \mathrm{~cm}^{-1}$ which shows the functional group $\mathrm{C}=\mathrm{C}$ on cross-bound sludge and polypropylene, there are a wave number $1255.38 \mathrm{~cm}-1$ which is a $\mathrm{CO}$ functional group which indicates an interaction between polypropylene plastic waste, coconut fiber, and sludge, in a chemical bond as well as some typical groups such as polypropylene waste without a mixture of natural ingredients. At wave number $1645.40 \mathrm{~cm}^{-1}$, weak absorption is observed, due to the absence of cross-linking agents, so that interactions between polymeric materials and natural materials are only occurred due to heating. 
RASĀYAN J. Chem.

Vol. 12 | No. 3 |1144 - 1150| July - September | 2019

Table-6: FT-IR Wavenumber of Composite

\begin{tabular}{c|c|c}
\hline Sample & Wavenumber $\left(\mathrm{cm}^{-1}\right)$ & Functional Group \\
\hline & 3346,41 & O-H stretching \\
PPW: Coconut Fiber: Sludge & 3193,31 & C-H stretching \\
(60:20:20) & 2841,00 & $\mathrm{CH}_{2}$ stretching \\
& 2722,12 & $\mathrm{C}^{-\mathrm{CH}_{3} \text { stretching }}$ \\
& 1645,40 & $\mathrm{C}=\mathrm{C}$ stretching \\
& 1255,38 & $\mathrm{C}-\mathrm{O}$ stretching \\
& 1452,00 & $\mathrm{CH}_{3}-\mathrm{CH}_{2}$ stretching \\
& 1358,10 & $\mathrm{CH}_{3}$ bending \\
\hline
\end{tabular}

\section{CONCLUSION}

Composite wall panels fabricated through addition of primary sludge from paper mill waste possessed following physicochemical properties: flexural strength of $9.6 \mathrm{~N} / \mathrm{mm}^{2}$, modulus of elasticity of 2,640 $\mathrm{N} / \mathrm{mm}^{2}$, melting point at $161,21^{\circ} \mathrm{C}$, combustion point at $463,55^{\circ} \mathrm{C}$, decomposition point at $476.99^{\circ} \mathrm{C}$, carbon residue of $15.1 \%$, density of $1.093 \mathrm{~g} / \mathrm{cm}^{3}$, thickness swelling of $0.104 \%$, internal bond strength of $0.61 \mathrm{~N} / \mathrm{mm}^{2}$, and a good morphology and chemical interaction which meet the standard of EN 634-22007.

\section{ACKNOWLEDGMENT}

This research was financed by the Ministry of Industry of Indonesia through Research Grant: Penelitian Industri Terapan 2018.

\section{REFERENCES}

1. A.J. Barber, M.J. Crow, and J. Milsom, Sumatra: Geology, Resources and Tectonic Evolution, Geological Society of London, London (2005).

2. R. McCaffrey, Annu. Rev. Earth Planet Sci., 37(1), 345(2009), DOI: 10.1146/annurev.earth.031208.100212

3. J.C. Borrero, K. Sieh, M. Chlieh, and C.E. Synolakis. Procedings, Natl. Acad. Sci., 103(52), 19673(2006), DOI: 10.1073/pnas.0604069103

4. F.K. Alqahtani, G. Ghataora, M.I. Khan, and S. Dirar, Constr. Build. Mater., 148, 386(2017), DOI: 10.1016/j.conbuildmat.2017.05.011

5. F. Aslani and L. Wang, J. Clean Prod., 221, 202(2019), DOI: 10.1016/j.jclepro.2019.02.241

6. G. Wang, G. Zhao, G. Dong, Y. Mu, and C.B. Park, Compos. Sci. Technol., 168, (2018), DOI: 10.1016/j.compscitech.2018.09.009

7. C. Frazão, J. Barros, R. Toledo Filho, S. Ferreira, and D. Gonçalves, Cem. Concr. Compos., 86, 206(2018), DOI: 10.1016/j.cemconcomp.2017.11.008

8. Q. Zeng, T. Mao, H. Li, and Y. Peng, Energy Build., 174, 97(2018), DOI: 10.1016/j.enbuild.2018.06.031

9. S. Gezahegn, R. Lai, L. Huang, L. Chen, F. Huang, and N. Blozowski, et al. Sci. Total Environ., 664, 363(2019), DOI: $10.1016 /$ j.scitotenv.2019.01.408

10. N. Abbas, H.R. Khalid, G. Ban, H.T. Kim, and H.K. Lee, Constr. Build. Mater., 195, 312(2019), DOI: $10.1016 / j$.conbuildmat.2018.10.227

11. M. Valipour and K.H. Khayat, Constr. Build. Mater., 184, 320(2018), DOI: 10.1016/j.conbuildmat.2018.06.191

12. F. Zulkifli, J. Stolk, U. Heisserer, A.T.M. Yong, Z. Li, and X.M. Hu, Int. J. Impact. Eng., 129, (2019), DOI: 10.1016/j.ijimpeng.2019.02.005

13. S.T. Cholake, R. Rajarao, P. Henderson, R.R. Rajagopal, and V. Sahajwalla, J. Clean Prod., 151, 163(2017), DOI: 10.1016/j.jclepro.2017.03.074

14. A. Riccio, A. Raimondo, A. Sellitto, V. Acanfora, and M. Zarrelli, Procedia. Eng., 167, 64(2016), DOI: $10.1016 /$ j.proeng.2016.11.670

15. H. Wu, A. Chen, and S. Laflamme, Compos. Struct., 203, 300(2018), DOI: 10.1016/j.compstruct.2018.07.034 
RASĀYAN J. Chem.

Vol. 12 | No. 3 |1144 - 1150| July - September | 2019

16. V. Puri, P. Chakrabortty, S. Anand, and S. Majumdar, J. Build. Eng., 9, 52(2017), DOI: 10.1016/j.jobe.2016.11.010

17. T.K. Nye, C.P. Pantelides, and C.A. Burningham, Compos. Struct., 203, 624(2018), DOI: 10.1016/j.compstruct.2018.07.042

18. S. Siswosukarto, A. Saputra, and I.G.Y. Kafrain, Procedia. Eng., 171, 664(2017), DOI: 10.1016/j.proeng.2017.01.406

19. E.J. da Silva, M.L. Marques, F.G. Velasco, C. Fornari Junior, F.M. Luzardo, and M.M. Tashima, Sustain. Mater. Technol., 12, 44(2017), DOI: 10.1016/j.susmat.2017.04.003

20. M.J. Taufiq, M.R. Mansor, and Z. Mustafa, Compos. Struct., 189, 510(2018), DOI: 10.1016/j.compstruct.2018.01.090

21. R.S. Ramesh, K. Sadashivappa, and L. Sharanaprabhu, Mater.Today Proc., 5(11), 25331(2018), DOI: $10.1016 /$ j.matpr.2018.10.336

22. I. Turku, A. Keskisaari, T. Kärki, A. Puurtinen, and P. Marttila, Compos. Struct., 161, 469(2017), DOI: $10.1016 /$ j.compstruct.2016.11.073

23. R. Negi and S. Suthar, J. Clean. Prod., 201, 842(2018), DOI: 10.1016/j.jclepro.2018.08.068

24. T. Meyer, P. Amin, D.G. Allen, and H. Tran, J. Environ. Chem. Eng., 6, (2018), DOI: 10.1016/j.jece.2018.09.037

25. S.K. Singh, S. Kulkarni, V. Kumar, and P. Vashistha, J. Clean. Prod., 204, (2018), DOI: 10.1016/j.jclepro.2018.09.028

26. B.P. Raja, B.S.J. Retnam, A.S. Prabu, and A. Sundaram, Rasayan J. Chem., 11, 990(2018), DOI: $10.31788 /$ RJC.2018.1133048

27. S. Jothibasu, S. Mohanamurugan, and A. Vinod, Rasayan J, Chem, 11, 1255(2018), DOI: 10.31788/RJC.2018.1133096

28. I.P. Mahendra, B. Wirjosentono, Tamrin, H. Ismail, and J.A. Mendez, Rasayan J. Chem., 12, 635(2019), DOI: 10.31788/RJC.2019.1225089

29. E. Pelita, T.R. Hidayani, and A. Akbar. IOP Conf Ser Mater Sci Eng, 223, (2017), DOI:10.1088/1757-899X/223/1/012060.

30. P.N. Khanam and M.A.A. AlMaadeed, Adv. Manuf. Polym. Compos. Sci., 1(2), 63(2015), DOI: 10.1179/2055035915Y.0000000002

31. A.A. Klyosov, Wood-plastic Composites, John Wiley \& Sons, New Jersey (2007).

32. M. Haddar, A. Elloumi, A. Koubaa, C. Bradai, S. Migneault, and F. Elhalouani, J. Polym. Environ., 25(3), 617(2017), DOI: 10.1007/s10924-016-0837-9

33. S. Kim, H.-J. Kim, and J.C. Park, Resour. Conserv. Recycl., 53(12), 674(2009), DOI: 10.1016/j.resconrec.2009.04.021

[RJC-5345/2019] 